\title{
THE DIGITAL TRANSFORMATIONS AND ENHANCE THE MARKET POSITIONS: INSIGHT THE R-A THEORY
}

\author{
Steven Sukianto, Martawi and Wilhelmus Hary Susilo* \\ POSTGRADUATE- Faculty of Economics and Business, University of Persada Indonesia Y.A.I \\ DOI: http://dx.doi.org/10.38193/IJRCMS.2021.3403
}

\begin{abstract}
The multinational- corporate should not operate within the misguide to implemented the vision and missions in the heterogeneous- industrial competitiveness and the consumers engagement, tight competitions, data, customer-based value and an incremental innovation. This study would be inquiry of fulfillment the research gap with the competition- advantage within market positions from the digital transformation within multinational-firms. The novelty research model has the intervening variables- the powerful digital marketing and the focus creation in customer- value that could be more exploring the R-A theory. Furthermore, the research methods conducted with the confirmed strategy in structural equation modeling within an entire latent variable.
\end{abstract}

KEYWORDS: Enhance digital transformations, the market positions, R-A Theory.

\section{INTRODUCTION}

The digital marketing capabilities among multinational firms have many misguide and gap to improve the marketing performance and pursue the market- position, that it intended and attempt the financial performance of the firms within the global pandemic era. The lack of this develop the digital marketing was the marketers need the robust platform, the distinctive digital capability, the building of the digital culture and the digital resources. (Herhausen et al., 2020)

Hence, the factors of the digital transformations within firms pertains; digital- channel consumer engagement, tight competitions, data based, customer value and innovations that have been the interesting of confirmed result of many research (Vivek et al., 2012), (Hollebeek, 2012), (Harrigan et al., 2017), (Bitter and Grabner-Kräuter, 2016), (Hamilton, 2009, Haifen et al., 2017, Glińska-Neweś et al., 2017, Straker and Wrigley, 2016).

Actually, an inquiry the process for the impact to the competitive advantage- market positions still have minus exploring the meaning in multinational- firms as the result research in many scholars analysis, that would making some research gap that must be fulfill the novelty variables as the new models to be confirm within market- based management research.(Bürkner and Lange, 2017, Wang et al., 2017, Straker and Wrigley, 2016, Walmsley, 2016, Järvinen and Karjaluoto, 2015) The objective 
of this study would be develop the new conceptual model to fulfilling the research gap between the relation on the digital transformations within firms to the competitive advantage- market positions and its implication the superior-financial performance. The research gap in this an investigates conducted with the new research model to Attempt Superior- Financial Performance within MultinationalCorporations with novelty variables the powerful digital marketing and the focus creation in customer value such as intervening variables within a research model. (Li, 2010, Järvinen and Karjaluoto, 2015, Obal and Lancioni, 2013, Walmsley, 2016, Demirkan and Spohrer, 2014, Geraerdts, 2012, Landroguez, 2013, Kim et al., 2013)

Furthermore, the marketing within accountable- based and entire multinational- corporations have many ways to create some digitalize marketing planning, and should be determining with the newest big data that could integrated in many sources, the modern incremental innovations- competitively within intelligent for face the tight competition, the development for the resources- advantage and could attempt the best market position to multinational market for achieve the big opportunity to gain the profit within business ethic and good service quality to entire consumers (Aima, Susilo, Purwanto and Wiratih, 2015). Moreover, the entire multinational corporate should making attentions' within digital customer engagement to predict the interaction between digital channel an end-user, the powerful digital marketing, the focus for create on customer value on the multinational firm that conducted by digitalize era to affect the competitive advantage- market position. (Anselmsson and Bondesson, 2015, C. Roach et al., 2014, Ben Aissa and Goaied, 2016, Takata, 2016)

\section{Literature review and hypothesis development}

Indeed, in this analysis was investigated model of variables that conducted to pursue the contributions for grand R-A theory and to develop of the body of knowledge and more empirical in the result, also for the contributions to the management implications as actions plan and the executive summary for strategies within entire multi-national enterprise. Moreover, in this inquiry conducted with practice theory, that correlated within the R-A Theory for attempted the robust competitiveness advantage in market position and the superior financial performance for long-run operations in business.

\section{The R-A Theory and Develop on Body of Knowledge}

Resources- advantage theory could exploring some knowledge about competition between Entire Corporation in heterogeneous venture for doing business, and then the sustainable competitive advantage should have the rigor basis as the foundation of the corporation to design the structures, bundles and provide the hi-organization's resources and have agile management to moving forward and winning the competitions for lung-run business. (Hunt, 2013, Hunt, 2015, Hunt and Morgan, 1995) 
The scholar has developed the grand theory to fulfill the research gap and could make the contribution for the body of knowledge to enlightened and have the novelty result from doing empirical research as follow, the figure 1 below:

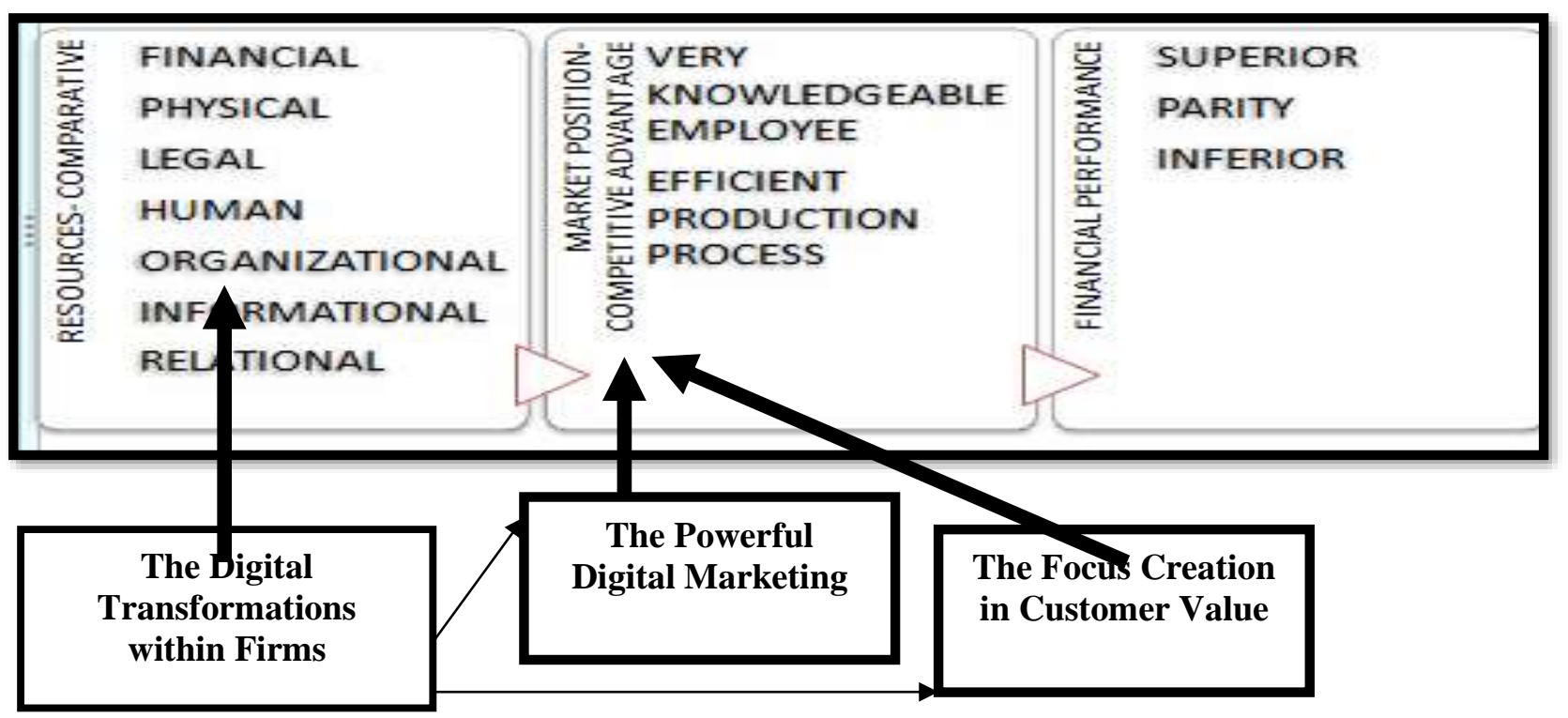

Figure 1. The R-A Theory and Develop on Body of Knowledge within the Digitalized Marketing

\section{Proposed the Framework and Hypothesis Development}

Actually, the research framework of Superior- Financial Performance within MultinationalCorporations should have for development to fulfillment the research gap for finding the knowledge to improvement the superior- financial performance within heterogeneous industries and contributions for R-A Theory in the body of knowledge (Hunt, 2015, Hunt, 2013, Hunt and Arnett, 2006). Furthermore, the scholar could more achieve the contributions to body of knowledge within the strategic choice theory, that analysis focused on; the tight related between marketing managers and their choice, the faster change in marketplace and the correlation the managers with marketplace.

This middle range- theoretical could bridging to the practice theory in practical management for doing business. Hence, The Stakeholder theory could support managers to understanding about the moral and value for managing the firms with well ethics in business within shareholders and many groups. (Hooks and Stewart, 2015, Ren et al., 2016, Hernández-Perlines, 2016, Carvalho and Gomes, 2017, Forthofer et al., 2016) 


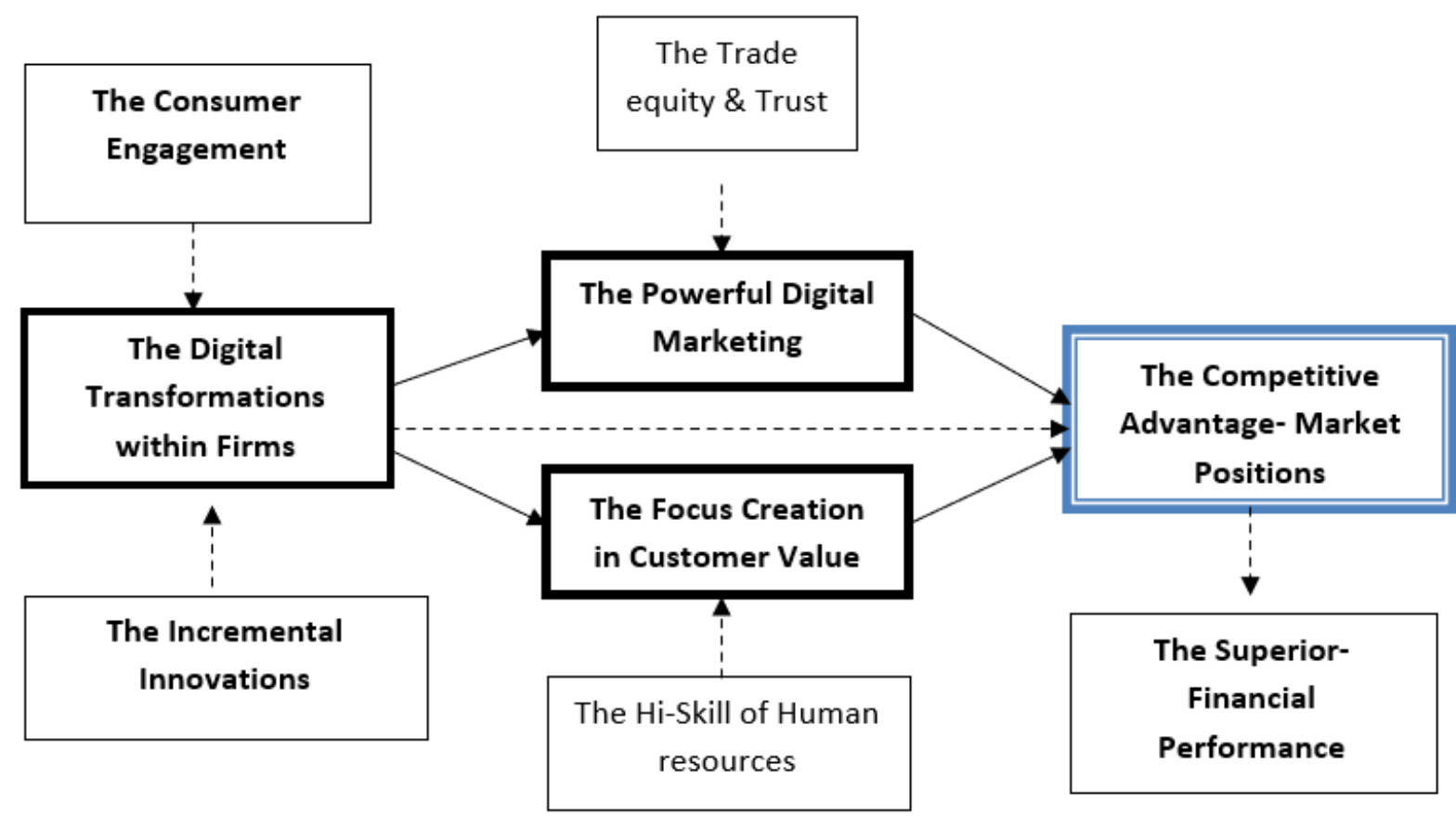

Fig.2. The Research Model to Attempt Superior-Market Position- Corporations

(Source: Develop from an Authors- concept)

\section{The digital transformations within firms and the digital marketing.}

The digital transformation was conducted to develop the $R \& D$ department of the firms and the firm policies from board of director to the deployment firms' strategies and also determine the transforming of the consumer behavior, the social mobility, network and the relationship between corporate and among customer. (Erz and Heeris Christensen, 2018, Ponte and Campos, 2018, Fonfara et al., 2016, Erevelles et al., 2016)

Furthermore, the digital marketing have the art for the long-run business that the marketers have focus to develop within this strategy for improve the customer commitment and the consumer loyalty. Hence, the digital marketing capabilities was also have some gaps comprises; the capabilities, the digital resources and the future decisions in business. (Reydet and Carsana, 2017, Roggeveen et al., 2016, Herhausen et al., 2020, Canhoto et al., 2016, Cenamor et al., 2017)

\section{The digital transformation and consumer value.}

The distinctive-digital transformation (an essential and readiness of among firms) would make some movement for the consumer value in this global pandemic era and the marketer should make some improvement to create the consumer value within the strategic that it friendly with among consumer 
and pursue the brand position, capture value and complex relationship would lead to marketingperformance. (Rowles and Brown, 2017) (Jeng and Yeh, 2015). (Yeh et al., 2016, Barrena and Sánchez, 2013, Tasci, 2016, Aspara and Tikkanen, 2012)

Further, the consumer value have many diversity and could improvement by the creative marketer within the team digital marketing determining the value attitude approach and the social value, and also always enhance value and the relationship value. (Aspara and Tikkanen, 2012, Hasman and Østerdal, 2004, Lu and Keung, 2019, Sakari Soininen et al., 2013, Gökbulut Özdemir, 2013, Kirkley, 2016, Wong and Dean, 2009, Nguyen Tho and Nguyen Trang, 2011, Korsgaard and Anderson, 2011, Gordon et al., 2018)

\section{The digital transformations within firms and the market positions.}

The platform of digital marketing, the resources and capabilities of the digital marketing would leverage to the market position, the responsive market, the market knowledge and market orientation and also determine the market- structure of entire multi-national firms in Jakarta. (Sørensen, 2009, Chen et al., 2015, Herhausen, 2016, Wong and Wu, 2013, Liu et al., 2010)

Recently the marketer should understand the market to deliver the product value of many customers' and determine the market evolution, the cross-market validity that it could impact to the market performance. (Dijk et al., 2015, Tournois, 2013, Tasci, 2018, Karakaya et al., 2016)

Furthermore, the market position would impact to the sustain and long- rung business within the multinational venture and face the competitiveness in business to growth a firm on the globalpandemic era. (Tan et al., 2014, Erz and Heeris Christensen, 2018, Echeverri-Carroll et al., 2018, Ulaga and Loveland, 2014)

The confirming strategies for hypothesis in these inquiries the conceptual research model on figure 2 above, as follow:

$\mathrm{H}_{1}$. The digital transformations within firms is positively related to the powerful digital marketing.

$\mathrm{H}_{2}$. The digital transformations within firms is positively related to the focus- creation in customer value.

$\mathrm{H}_{3}$. The powerful digital marketing is positively related to the competitive advantage- market positions.

$\mathrm{H}_{4}$. The focus creation in customer- value is positively related to the competitive advantage- market positions. 


\section{RESEARCH METHOD}

a. Sample and data collection

The respondent in digital era as which participated that daily used the consumers good which have the newest technology- product within total sampling. The population will border within the sample frame base on SEM- multivariate requirement between 100-300 respondents. (Mathwick et al., 2010, Thomas, 2013, Sarstedt et al., 2016, Hasan and Ali, 2015) The data would be collected from in the central Jakarta, which used the compatible computer in daily activities. The sample in this study conducted with the clustered- area sampling. (Sekaran and Bougie, 2016).

\section{b. Measurement of variables}

The survey was conduct within the self-administered questionnaire that uses the rating scale for entire latent variables to make the response for use the newest technologies consumers goods brand (Sekaran and Bougie, 2016) (Susilo, 2017, Susilo, 2020). Moreover, the tools- instrument have the independently cross-sectional collected method and conducted with the rating scale as an interval data scale ( 1 to 10 very agree) Hence, the validity and reliability construct test that conducted with measurement model in structural equation modeling among variables. (Susilo, 2020) (Hair, Black, Babin and Anderson, 2010)

The indicators of the market position were comprises; pursue the competitive advantage of the firms, the knowledgeable employee and the efficiency- production process. Further, the digital transformation within firms has indicators, pertains; the essentials and the readiness, and the intervening variable have the powerful digital marketing (multitasking and hi-performance) and the focus creation in customer value (the newest-technological and user friendly.

\section{Data analysis, The Model of Fitting and Hypothesis testing}

\section{a. Data analysis}

The data analysis would conducted to the structural equation modeling, because entire the variables were latent characteristics.(Hair et al., 2011, Hair et al., 2010a) Moreover, the two step approach have pertains; measurement model and the structural hybrid full model and used the confirmatory strategies were conducted in this multivariate data analysis, with a testing the validity and the reliability construct, also synthesis the fitting model and hypothesis proved (Hair et al., 2010b, Sarstedt et al., 2016)(Susilo and Yulius, 2017). The research result would have for the data analysis pertain:

- A sensitivity analysis: the test indicated did not have the outlier and missing value that conducted with SPSS and the $\mathrm{z}$ value <2.50. (Susilo, 2020, Susilo, 2017)

- An univariate and multivariate of normality test: 


\section{b. The Model of Fitting and Hypothesis testing}

The goodness of fit research model could be analyzed within the indexed value such as; GFI, NFI, RMSEA, CHI-SQUARE and p-value. (Hair et al., 2010a) (Hair et al., 2010b, Sarstedt et al., 2016) Moreover, the entire hypothesis confirmed was conducted with t value $>2$. (Hair et al., 2010a)

\section{Conclusions and research contribution.}

a. Conclusions:

Indeed, our research result could successfully to confirm entire hypotheses, if it will have the greatest value and can find to pursue the market positions on multinational corporations. The scholar hope the fulfillment the research gap within the new research model can effectively to achieve the market position with the on- line platform within the digital marketing and would leverage to the customer value.

\section{b. Research contribution:}

The research contributions were within 2 (two) area that pertain; first, the contributions for theoretical implications to the body of knowledge of the recourses advantage, and the market position of the multi- national venture. Moreover, the conducted with R-A theory as the explanations and predicted the relationship for the attempt the financial performance that it will investigate on the market- based research in management.

\section{Acknowledgement}

Thank you so much to the Expertise and Experience Learning Club, Faculty of Business and Management, University of Persada Indonesia Y.A.I. To my colleague and students. To In Kind Workshops The NEW- E\&EL CLUB LABORATORY FEB UPI Y.A.I team.

\section{Declaration of conflicting interests}

The scholar declared no potential conflicts of interest with respect to the investigated, authorship, publication within this manuscript.

\section{Funding}

The authors did not receive the financial support for this research and publication of this manuscript.

ORCID:000-0002-6758-1159, URL: orcid.org/0000-0002. And SCOPUS ID: 56539508300.

\section{REFERENCES}

ANSELMSSON, J. \& BONDESSON, N. 2015. Brand value chain in practise; the relationship between mindset and market performance metrics: A study of the Swedish market for FMCG. Journal of Retailing and Consumer Services, 25, 58-70.

ASPARA, J. \& TIKKANEN, H. 2012. Creating novel consumer value vs. capturing value: Strategic emphases and financial performance implications. Journal of Business Research. 
BARRENA, R. \& SÁNCHEZ, M. 2013. Neophobia, personal consumer values and novel food acceptance. Food Quality and Preference, 27, 72-84.

BEN AISSA, S. \& GOAIED, M. 2016. Determinants of tourism hotel market efficiency. International Journal of Culture, Tourism and Hospitality Research, 10, 173-190.

BITTER, S. \& GRABNER-KRÄUTER, S. 2016. Consequences of customer engagement behavior: when negative Facebook posts have positive effects. ElectronMarkets, 26, 13.

BÜRKNER, H.-J. \& LANGE, B. 2017. Sonic capital and independent urban music production: Analysing value creation and 'trial and error' in the digital age. City, Culture and Society.

C. ROACH, D., RYMAN, J. \& WHITE, J. 2014. Culture, conduct and innovation: a deconstruction of market orientation. Journal of Research in Marketing and Entrepreneurship, 16, 128-145.

CANHOTO, A. I., QUINTON, S., JACKSON, P. \& DIBB, S. 2016. The co-production of value in digital, university-industry R\&D collaborative projects. Industrial Marketing Management, 56, 86-96.

CARVALHO, N. \& GOMES, I. 2017. Knowledge Sharing between Enterprises of the Same Group. International Journal of Knowledge Management, 13, 34-52.

CENAMOR, J., RÖNNBERG SJÖDIN, D. \& PARIDA, V. 2017. Adopting a platform approach in servitization: Leveraging the value of digitalization. International Journal of Production Economics, 192, 54-65.

CHEN, K., KOU, G., SHANG, J. \& CHEN, Y. 2015. Visualizing market structure through online product reviews: Integrate topic modeling, TOPSIS, and multi-dimensional scaling approaches. Electronic Commerce Research and Applications, 14, 58-74.

DEMIRKAN, H. \& SPOHRER, J. 2014. Developing a framework to improve virtual shopping in digital malls with intelligent self-service systems. Journal of Retailing and Consumer Services, 21, 860-868.

DIJK, M., ORSATO, R. J. \& KEMP, R. 2015. Towards a regime-based typology of market evolution. Technological Forecasting and Social Change, 92, 276-289.

ECHEVERRI-CARROLL, E. L., ODEN, M. D., GIBSON, D. V. \& JOHNSTON, E. A. 2018. Unintended consequences on gender diversity of high-tech growth and labor market polarization. Research Policy, 47, 209-217.

EREVELLES, S., FUKAWA, N. \& SWAYNE, L. 2016. Big Data consumer analytics and the transformation of marketing. Journal of Business Research, 69, 897-904.

ERZ, A. \& HEERIS CHRISTENSEN, A.-B. 2018. Transforming Consumers Into Brands: Tracing Transformation Processes of the Practice of Blogging. Journal of Interactive Marketing, 43, 69-82.

FONFARA, K., RATAJCZAK-MROZEK, M. \& LESZCZYŃSKI, G. 2016. Change and transformation of networks and relationships - Fundamental aspects of business reality. Industrial Marketing Management, 58, 187-189.

FORTHOFER, M., BURROUGHS-GIRARDI, E., STOISOR-OLSSON, L., WILCOX, S., SHARPE, P. A. \& PEKURI, L. M. 2016. Use of formative research and social network theory to develop a group walking intervention: Sumter County on the Move! Eval Program Plann, 58, 28-34.

GERAERDTS, R. 2012. Customer value creation: A journey in the search of excellence. Industrial Marketing Management, 41, 11-12. 
ISSN 2582-2292

Vol. 3, No. 04 July-Aug; 2021

GLIŃSKA-NEWEŚ, A., SUDOLSKA, A., KARWACKI, A. \& GÓRKA, J. 2017. INNOVATIONS AMONG PEOPLE. HOW POSITIVE RELATIONSHIPS AT WORK CAN TRIGGER INNOVATION CREATION. E+M Ekonomie a Management, 20, 84-100.

GÖKBULUT ÖZDEMIR, Ö. 2013. Entrepreneurial marketing and social value creation in Turkish art industry: An ambidextrous perspective. Journal of Research in Marketing and Entrepreneurship, 15, 39-60.

GORDON, R., DIBB, S., MAGEE, C., COOPER, P. \& WAITT, G. 2018. Empirically testing the concept of value-in-behavior and its relevance for social marketing. Journal of Business Research, 82, 56-67.

HAIFEN, L., MENGYA, C. \& JINGQIN, S. 2017. How management innovations are successfully implemented? An organizational routines' perspective. Journal of Organizational Change Management, 30, 456-486.

HAIR, J. F., BLACK, W. C., BABIN, B. J. \& ANDERSON, R. E. 2010a. Multivariate Data Analysis 7th_Edition, Pearson Prentice Hall.

HAIR, J. F., JR., ANDERSON, R. E. \& R.L., T. 2010b. Multivariate Data Analysis With Readings, Englewood Cliffs, NJ: Prentice Hall.

HAIR, J. F., RINGLE, C. M. \& SARSTEDT, M. 2011. PLS-SEM: Indeed a Silver Bullet. The Journal of Marketing Theory and Practice, 19, 139-152.

HAMILTON, J. 2009. Building a targeted pharmacy customer engagement approach. International Journal of Pharmaceutical and Healthcare Marketing, 3, 381-396.

HARRIGAN, P., EVERS, U., MILES, M. P. \& DALY, T. 2017. Customer engagement and the relationship between involvement, engagement, self-brand connection and brand usage intent. Journal of Business Research.

HASAN, Z. \& ALI, N. A. 2015. The Impact of Green Marketing Strategy on the Firm's Performance in Malaysia. Procedia - Social and Behavioral Sciences, 172, 463-470.

HASMAN, A. \& ØSTERDAL, L. P. 2004. EQUAL VALUE OF LIFE AND THE PARETO PRINCIPLE. Economics and Philosophy, 20, 19-33.

HERHAUSEN, D. 2016. Unfolding the ambidextrous effects of proactive and responsive market orientation. Journal of Business Research, 69, 2585-2593.

HERHAUSEN, D., MIOČEVIĆ, D., MORGAN, R. E. \& KLEIJNEN, M. H. P. 2020. The digital marketing capabilities gap. Industrial Marketing Management, 90, 276-290.

HERNÁNDEZ-PERLINES, F. 2016. Entrepreneurial orientation in hotel industry: Multi-group analysis of quality certification. Journal of Business Research, 69, 4714-4724.

HOLLEBEEK, L. D. 2012. The customer engagement/value interface: An exploratory investigation. Australasian Marketing Journal (AMJ).

HOOKS, J. \& STEWART, R. 2015. The changing role of accounting: From consumers to shareholders. Critical Perspectives on Accounting, 29, 86-101.

HUNT, S. D. 2013. A general theory of business marketing: R-A theory, Alderson, the ISBM framework, and the IMP theoretical structure. Industrial Marketing Management, 42, 283-293.

HUNT, S. D. 2015. Marketing theory: foundations, controversy, strategy, resource-advantage theory, New York, USA, Routledge Taylor \& Francis Group.

HUNT, S. D. \& ARNETT, D. B. 2006. Does marketing success lead to market success? Journal of Business Research, 59, 820-828. 
HUNT, S. D. \& MORGAN, R. M. 1995. The comparative advantage theory of competition. The Journal of Marketing, 1-15.

JÄRVINEN, J. \& KARJALUOTO, H. 2015. The use of Web analytics for digital marketing performance measurement. Industrial Marketing Management.

JENG, M.-Y. \& YEH, T.-M. 2015. The effect of consumer values on the brand position of green restaurants by means-end chain and laddering interviews. Service Business, 10, 223-238.

KARAKAYA, A., Y1LMAZ, K. \& DEMIRAL, G. 2016. Strategic Capabilities of Retail Market Managers: A Field Research in Karabuk. Procedia - Social and Behavioral Sciences, 235, 93100.

KIM, D., CAVUSGIL, S. T. \& CAVUSGIL, E. 2013. Does IT alignment between supply chain partners enhance customer value creation? An empirical investigation. Industrial Marketing Management, 42, 880-889.

KIRKLEY, W. W. 2016. Entrepreneurial behaviour: the role of values. International Journal of Entrepreneurial Behavior \& Research, 22, 290-328.

KORSGAARD, S. \& ANDERSON, A. R. 2011. Enacting entrepreneurship as social value creation. International Small Business Journal, 29, 135-151.

LANDROGUEZ, S. M. 2013. Developing an integrated vision of customer value. Journal of Services Marketing, 27, 234-244.

LI, Y.-M. 2010. Pricing digital content distribution over heterogeneous channels. Decision Support Systems, 50, 243-257.

LIU, Y., LI, Y. \& XUE, J. 2010. Transfer of market knowledge in a channel relationship: Impacts of attitudinal commitment and satisfaction. Industrial Marketing Management, 39, 229-239.

LU, H.-T. \& KEUNG, E. C. 2019. Entry mode and firm value: Evidence from investing firms in mainland China. Pacific-Basin Finance Journal, 58.

MATHWICK, C., WAGNER, J. \& UNNI, R. 2010. Computer-Mediated Customization Tendency (CMCT) and the Adaptive e-Service Experience. Journal of Retailing, 86, 11-21.

NGUYEN THO, D. \& NGUYEN TRANG, T. M. 2011. Enhancing relationship value between manufacturers and distributors through personal interaction: Evidence from Vietnam. Journal of Management Development, 30, 316-328.

OBAL, M. \& LANCIONI, R. A. 2013. Maximizing buyer-supplier relationships in the Digital Era: Concept and research agenda. Industrial Marketing Management, 42, 851-854.

PONTE, L. F. \& CAMPOS, R. D. 2018. Taste Transformation in the Context of Social Mobility. BAR - Brazilian Administration Review, 15.

REN, M., HU, Z. \& JAIN, H. 2016. A conciliation mechanism for self-organizing dynamic small groups. Springerplus, 5, 800.

REYDET, S. \& CARSANA, L. 2017. The effect of digital design in retail banking on customers' commitment and loyalty: The mediating role of positive affect. Journal of Retailing and Consumer Services, 37, 132-138.

ROGGEVEEN, A. L., NORDFÄLT, J. \& GREWAL, D. 2016. Do Digital Displays Enhance Sales? Role of Retail Format and Message Content. Journal of Retailing, 92, 10.

SAKARI SOININEN, J., PUUMALAINEN, K., SJÖGRÉN, H., SYRJÄ, P. \& DURST, S. 2013. Entrepreneurial orientation in small firms - values-attitudes-behavior approach. International Journal of Entrepreneurial Behavior \& Research, 19, 611-632. 
SARSTEDT, M., HAIR, J. F., RINGLE, C. M., THIELE, K. O. \& GUDERGAN, S. P. 2016. Estimation issues with PLS and CBSEM: Where the bias lies! Journal of Business Research, 69, 3998-4010.

SØRENSEN, H. E. 2009. Why competitors matter for market orientation. European Journal of Marketing, 43, 735-761.

STRAKER, K. \& WRIGLEY, C. 2016. Designing an emotional strategy: Strengthening digital channel engagements. Business Horizons, 59, 339-346.

SUSILO, W. H. 2017. Internation Marketing Research, Jakarta, INA, IN MEDIA.

SUSILO, W. H. 2020. The Business Research: The Competency\& Confident- Building Approach, RIGA LATVIA, LAP LAMBERT Academic Publihing.

TAKATA, H. 2016. Effects of industry forces, market orientation, and marketing capabilities on business performance: An empirical analysis of Japanese manufacturers from 2009 to 2011. Journal of Business Research.

TAN, C. S. L., SMYRNIOS, K. X. \& XIONG, L. 2014. What drives learning orientation in fast growth SMEs? International Journal of Entrepreneurial Behavior \& Research, 20, 324-350.

TASCI, A. D. A. 2016. A critical review of consumer value and its complex relationships in the consumer-based brand equity network. Journal of Destination Marketing \& Management, 5, 171-191.

TASCI, A. D. A. 2018. Testing the cross-brand and cross-market validity of a consumer-based brand equity (CBBE) model for destination brands. Tourism Management, 65, 143-159.

THOMAS, E. 2013. Supplier integration in new product development: Computer mediated communication, knowledge exchange and buyer performance. Industrial Marketing Management, 42, 890-899.

TOURNOIS, L. 2013. Total Market Orientation, Customer Value, And Market Performance From A Dual Perspective. Journal of Applied Business Research, 29, 1157.

ULAGA, W. \& LOVELAND, J. M. 2014. Transitioning from product to service-led growth in manufacturing firms: Emergent challenges in selecting and managing the industrial sales force. Industrial Marketing Management, 43, 113-125.

VIVEK, S. D., BEATTY, S. E. \& MORGAN, R. M. 2012. Customer Engagement: Exploring Customer Relationships Beyond Purchase. Journal of Marketing Theory and Practice, 20, 122-146.

WALMSLEY, B. 2016. From arts marketing to audience enrichment: How digital engagement can deepen and democratize artistic exchange with audiences. Poetics, 58, 66-78.

WANG, W.-L., MALThOUSE, E. C., CALDER, B. \& UZUNOGLU, E. 2017. B2B content marketing for professional services: In-person versus digital contacts. Industrial Marketing Management.

WONG, A. \& DEAN, A. 2009. Enhancing value for Chinese shoppers: The contribution of store and customer characteristics. Journal of Retailing and Consumer Services, 16, 123-134.

WONG, I. A. \& WU, J. S. 2013. Understanding casino experiential attributes: An application to market positioning. International Journal of Hospitality Management, 35, 214-224.

YEH, C.-H., WANG, Y.-S. \& YIEH, K. 2016. Predicting smartphone brand loyalty: Consumer value and consumer-brand identification perspectives. International Journal of Information Management, 36, 245-257. 